Revista Iberoamericana, Vol. LXXVII, Núms. 236-237, Julio-Diciembre 2011, 865-883

\title{
EL DRAMA POR LA SOBREVIVENCIA: ILUMINACIONES PROFANAS, ALEGORÍAS Y LA ESTÉTICA REDENTORA DE LA PROFUSIÓN EN LA VENDEDORA DE ROSAS
}

\author{
POR \\ LizARDO HERRERA \\ Whittier College
}

\section{El MATERIALISMO DE LA REDENCIÓN MESIÁNICA Y LA ALEGORÍA}

Susan Buck-Morss, en The Dialectics of Seeing, divide el pensamiento de Walter Benjamin en tres períodos: el primero de 1917 al 29, en donde hay un interés por la teología del judaísmo con referencias al lenguaje de la creación o la figura del Mesías; el segundo de 1929 al 34, en el cual entra en contacto con las ideas revolucionarias del marxismo; y un tercero, de 1934 al 40, en donde Benjamin no abandona sus ideas anteriores, sino que por el contrario intenta armonizar dos líneas de reflexión que hasta ese momento se consideraban irreconciliables. Una buena muestra de este tercer período son las Tesis de la filosofía de la historia, escritas en 1940. En la primera tesis, por ejemplo, interactúan un muñeco vestido de turco -el materialismo histórico- y un enano jorobado -la teología- en torno a una mesa de ajedrez. El primero está sentado a la vista de todos, mientras que el segundo, escondido debajo de la mesa, dirige los movimientos del muñeco gracias a un complejo sistema de cuerdas. Aunque parecería que Benjamin favorece a la teología, a quien entrega el control del muñeco, al final de la tesis paradójicamente escribe que el materialismo histórico "puede competir sin más con cualquiera, siempre que ponga a su servicio a la teología, la misma que hoy, como se sabe, además de ser pequeña y fea, no debe dejarse ver por nadie” (17).

La figura de los cuadrantes sugerida por Buck-Morss nos ayuda a entender mejor esta paradoja. El cuadrante, en este caso, estaría formado por dos coordenadas: a) el materialismo histórico y b) la teología. En el punto de intersección entre ambas coordenadas, se produce una dialéctica muy peculiar porque más que una síntesis en la que se resuelven las contradicciones entre las fuerzas en pugna o la emergencia de una nueva etapa histórica, se trata de una dialéctica parada en donde la una fuerza interrumpe el avance de la otra y viceversa. Según Benjamin, esta doble detención sucede como una explosión y gracias a ella podemos experimentar el Jetztzeit o tiempo pleno del ahora.

Bolívar Echeverría, en "El ángel de la historia y el materialismo histórico”, entiende que en la primera tesis benjamiana, "el juego de ajedrez es la filosofía” (28). El muñeco 
-el traje de la cientificidad-, indica, es un disfraz que usa el materialismo para mostrarse en público, pues de lo contrario corre el riesgo de ser ignorado en el debate filosófico. Sin embargo, el historiador materialista, advierte, debe tener en cuenta que el traje del científico es sólo una treta que esconde un gran secreto: la teología, pero ella es impresentable. Si es vista, el discurso científico la descalificaría como el regreso de la superstición en una “época cuya misión consiste todavía en el desarrollo de la estructura técnico-científica de los medios de producción, una estructura que no puede afirmarse si no es como la negación de la estructura tecno-mágica de los mismos” (30). En otras palabras, en la medida en que la teología benjaminiana es un enano jorabado, carece de la autoridad de la verdad revelada, más bien se trata de una de índole materialista en la que, según Echeverría, el azar es “el fundamento contingente de [...] su horizonte de inteligibilidad” (30).

La teología materialista al igual que la trascendental contempla la redención, pero su mesianismo no coincide con la llegada de un Mesías ni con el Juicio Final, sino, por el contrario, con la interrupción de estos mitos. ${ }^{1}$ Según Benjamin,

[...] en la idea que nos hacemos de la felicidad late inseparablemente la de la redención. Lo mismo sucede con la idea del pasado, de la que la historia hace asunto suyo. El pasado lleva un índice oculto que no deja de remitirlo a la redención [...] También a nosotros, entonces, como a toda otra generación, nos ha sido conferida una débil fuerza mesiánica a la cual el pasado tiene derecho a dirigir sus reclamos. Reclamos que no se satisfacen fácilmente [...]. (Tesis 18; énfasis mío)

Si la historia hace asunto suyola idea de la felicidad y del pasado, entonces la redención ocurre cuando la teología entra en contacto con la lucha de clases confundiéndose con un momento revolucionario porque aquello que exige ser redimido es la experiencia de las clases dominadas en cuya idea de la felicidad late la promesa redentora de una sociedad sin clases. Asimismo, en tanto el ángel de la historia mira hacia atrás, ${ }^{2}$ este instante revolucionario y mesiánico no obedece a un proceso teleológico que contempla una marcha imparable hacia el progreso; al contrario, se nutre más bien de una memoria oprimida, cuyo origen se encuentra en una idea de la felicidad -en tanto es una promesa frustrada-que demanda su realización plena. En consecuencia, estamos ante una memoria

1 Benjamin se opone al mito porque éste concibe "el mundo como un castigo. Un castigo que genera sus castigados” (Tesis 40). En los relatos míticos, de la misma manera, todo está predestinado y el futuro está clausurado, es decir, no hay lugar para la emergencia de lo nuevo.

2 Las Tesis son una crítica al historicismo porque éste vuelca su mirada completamente hacia el futuro. En la novena tesis, el Angelus Novus, por el contrario, está de espaldas y observa el pasado; pero el huracán del progreso también lo arrastra a él evitando que pueda regresar en el tiempo para resucitar a los muertos, sólo puede ver con impotencia y lleno espanto los destrozos -las ruinas- que ese huracán deja a su paso.

Revista Iberoamericana, Vol. LXXVII, Núms. 236-237, Julio-Diciembre 2011, 865-883 
oprimida que, aunque proviene del pasado, lo que ha sido, se mantiene viva justamente porque aún no ha sido consumada. ${ }^{3}$

En otro texto, "Benjamin, la condición judía y la política”, Echeverría sostiene que las Tesis son "una radical corrección mesiánica al utopismo propio del socialismo revolucionario" (12). Al decir de este autor, en la reflexión benjaminiana confluyen dos cosmovisiones. Por un lado, el utopismo occidental en donde al mismo tiempo que se considera al orbe como una realidad imperfecta, se imagina una dimensión paralela en la cual se piensa un mundo mejor y, por eso, se desea reemplazar lo existente con lo imaginado. Por otro, según Echeverría, el espíritu mesiánico del judaísmo concibe una lucha permanente entre bien y mal en donde el último obtiene una victoria parcial sobre el primero, por lo que la historia se constituye en un devenir desastroso. La tradición judía, indica Echevarría, considera al ser humano como culpable por haber roto el equilibrio del ser y "por el pecado original de existir a su manera [...] tiene prohibido el goce del mundo en su plenitud o autenticidad" (17). En el judaísmo, sin embargo, existe la posibilidad de la redención, la cual revierte la catástrofe de la historia. En otros términos, al igual que el utopismo, el mesianismo judío supone que "la realidad dada posee en sí misma la potencia de ser una realidad diferente, radicalmente mejor que la efectiva o establecida" (14).

La “corrección” de Echeverría puede ser analizada en función de la figura del cuadrante. El mesianismo judío interrumpe el utopismo occidental y viceversa haciendo que en ese choque -estallido- "ambos se exijan mutuamente dar más de sí mismos" (17). El utopismo vuelca la mirada hacia el futuro, mientras que el mesianismo mira -al igual que el Angelus Novus- hacia el pasado. El primero concibe la historia como una marcha triunfal, mientras que el segundo la ve como una catástrofe. Pero la teología materialista no se guía tanto por los principios oficiales del judaísmo, sino por el misticismo mesiánico, posición herética que, de acuerdo con Ricardo Forster, "implica el anonadamiento de la Ley” (26-27). Es decir, el mesianismo materialista significa la interrupción de la trascendencia teológica o del Derecho mítico tanto del judaísmo como del cristianismo porque ambos transforman la vida en "an innocent bearer of guilt" (Herlinghaus 21). ${ }^{4}$ Si la redención mítica acepta la existencia del pecado original o, en el caso del cristianismo, implica la expiación de la culpa, la redención materialista elimina todo rastro de esa mancha porque ningún pecado tiene razón de ser. ${ }^{5}$

3 En Juegos del duelo, José Cuesta estudia la dialéctica entre lo sido y lo que aún no ha sido en Benjamin.

4 Benjamin explica la interrupción del Derecho mítico en "Para una crítica de la violencia" (1921), especialmente cuando cuestiona el sofisma de la sacralidad de la vida y también cuando establece un contraste entre la violencia mítica del Derecho y lo que llama violencia divina incruenta.

5 La interrupción mesiánica materialista ocurre cuando el presente y el pasado vivo forman ente sí una constelación indisoluble, la cual produce un estallido -un shock- en cuyo resplandor hace visible lo que aún no ha sido -una imagen dialéctica- que paradójicamente desparece en el mismo instante de su aparición.

Revista Iberoamericana, Vol. LXXVII, Núms. 236-237, Julio-Diciembre 2011, 865-883
ISSN 2154-4794 (Electrónico) 
Retomemos las imágenes del paraíso perdido y de la caída de la primera etapa. En su texto de 1919, "Sobre el lenguaje en general y el lenguaje de los seres humanos", Benjamin sugería que los objetos contienen una memoria que remite al tiempo de la creación: a la palabra creadora de Dios, la cual se "[...] hizo en parte receptora, aunque receptora de lenguaje. Tal recepción está dirigida hacia el lenguaje de las cosas, desde las cuales no obstante trasluce la muda magia de la naturaleza de la palabra de Dios" (68). Esto quiere decir que la chispa del lenguaje creador está en los objetos aunque simultáneamente ya no está allí porque de aquel resplandor inicial sólo quedan ruinas; es decir, se trata de una débil fuerza mesiánica que trasluce la muda magia de la palabra creadora. ${ }^{6}$ La imagen del paraíso perdido, por tanto, no es un período histórico al que se deba regresar ni implica la existencia de una divinidad a la que haya que rendir culto, sino justamente lo contrario. Estamos ante una propuesta crítica materialista en donde aquella experiencia oprimida coincide con la débil fuerza mesiánica; es decir, la chispa del lenguaje creador no está en un Dios exterior u omnipotente, sino en el propio mundo y, en especial, en esa memoria que reclama ser lo que debía ser y no lo que es.

\section{LA INVERSIÓN DE LO DIVINO Y LAS ILUMINACIONES PROFANAS}

En Cómo poner a actuar pájaros (1998), un documental sobre la realización de la película del director colombiano Víctor Gaviria, La vendedora de rosas (1998), Mónica Rodríguez cuenta que hablaba con Dios cuando se intoxicaba con sacol. ${ }^{7}$ A simple vista, se podría pensar que éste es un ejemplo de cómo se difunde la doctrina hegemónica del catolicismo por toda la sociedad, pero este punto de vista es unidireccional y reduccionista. Michael Taussig, en Chamanismo, colonialismo y hombre salvaje, sugiere que la imaginación o la religiosidad popular no es un ánfora vacía que recibe pasivamente los discursos hegemónicos. Ella, sostiene, consiste en un complejo campo de batalla en donde aparecen y desaparecen imágenes y narrativas; es decir, es el resultado de una lucha cotidiana por la significación de las imágenes religiosas, relatos, milagros, etc., en donde se transforma el sentido de los mismos con mucho dinamismo. La fe y las vivencias religiosas populares, entonces, constituyen "una epistemología de la imagen donde se juntan certeza y duda, desesperación con esperanza, en la que los sueños -en este caso los de la gente del pueblo pobre-reestablecen la significación de la imaginería

6 Echeverría, en Valor de uso y utopía afirma que "la Serpiente lleva a Adán a verse 'como Dios', dueño de 'una palabra que no sólo nombra, sino que al nombrar crea la cosa nombrada' (Benjamin), y a menospreciar el orden de la Creación, a tener el paraíso terrenal como 'poca cosa', a ponerlo como 'escaso' respecto de sus ambiciones" (109).

7 Los niños de la calle de Medellín llaman sacol o gale al pegamento. Por eso, usan indistintamente los términos engalochado o ensacolado para referirse a la intoxicación con esta droga.

Revista Iberoamericana, Vol. LXXVII, Núms. 236-237, Julio-Diciembre 2011, 865-883 ISSN 0034-9631 (Impreso) 
de la que se han apropiado instituciones de la clase dirigente, como la Iglesia, para colonizar las fantasías utópicas” (Chamanismo 213).

Transcribamos a continuación el testimonio de Rodríguez sobre su intoxicación:

\begin{abstract}
Estoy sola, hablo con el aire y el aire va a ser mi mejor amigo. Respiro algo fresco, me imagino lo que siento, me imagino una persona, hablo con ella. Quiero hablar y me desahogo, lloro en momentos. La mayoría de personas que a uno siempre se le viene en mente es Dios. Uno se imagina a ese Ser a lado, contemplándola, con uno allí y uno habla con Él. Uno dice las palabras que de pronto piensa que Él está diciendo, Él no dice mentiras, pa’ todos tiene un tiempo, tiene ojos tan grandes que a todos nos ve. Entonces, en el desespero, para que lo vea a uno, uno se arrodilla en un patio para mirar el cielo. “¡Miráme, miráme!, ¡estoy acá!”, sí, uno habla así. ¡Por un Dios, que a mí me ha pasado! Y me desahogo con Él, todo se lo confío y me siento tan bien. Como que descanso y ese taco que tenía lo suelto, salgo diferente, ya no soy la misma.
\end{abstract}

La fantasía utópica de Rodríguez es clara: un Dios que la ayude a soportar la desolación. En esta imagen confluyen su desesperación y sus esperanzas. Los ojos enormes de Dios, según la muchacha, miran a todos por igual, es decir, no son excluyentes y le dan a ella la misma importancia que a los demás. Cuando Rodríguez ve la imagen, llora y se alegra. Goza porque por fin hay alguien a quien puede confiarle sus secretos; sufre porque teme que Dios deje de verla o prestarle oído, por eso grita en el patio llena de angustia. De acuerdo con la doctrina oficial, Dios es amor y siempre dice la verdad; Rodríguez lo sabe, por eso pone en Él sus esperanzas, pero su gesto es bastante heterodoxo, no únicamente Lo mira, sino habla con Él. La transgresión es aún más grave: la muchacha transforma a la divinidad en un ser profano, una persona común a quien interpela exigiéndole a gritos que no la abandone. En este sentido, el poder de Dios no está en lo sagrado o en un ámbito fuera de este mundo, sino en el momento en que Éste pierde su autoridad divina confundiéndose con lo concreto; cuando escucha con paciencia lo que la muchacha tiene para contarle y, sobretodo, en el instante en que se materializa como una persona común -los labios de la joven-dando inicio a un diálogo pleno que transforma a Rodríguez. Esta vivencia religiosa, por tanto, es profana en la medida en que no comunica una verdad revelada y sólo redime una experiencia cotidiana que resiente el abandono.

En La vendedora, en la segunda alucinación de Mónica, ella y Andrea cruzan un puente sobre el río Medellín que conecta la comuna de Miramar, su barrio, con el centro de la ciudad. Momentos antes, la pequeña vendedora había peleado con su novio, Anderson, quien descaradamente aceptaba los galanteos de Marcela. Mónica, llena de ira, se separó del muchacho y también del resto de sus amigas a quienes consideraba cómplices de la traición. Ya cerca de la madrugada, se reencuentra con Andrea. Las dos se dirigen rumbo a Miramar y, cuando llegan al puente, Mónica mira la estatua de la Virgen. Poco a poco los efectos del sacol se hacen sentir, la niña ve que la imagen

Revista Iberoamericana, Vol. LXXVII, Núms. 236-237, Julio-Diciembre 2011, 865-883 ISSN 0034-9631 (Impreso) 
religiosa se confunde con la de su abuela. En el momento en el que la estatua adquiere el rostro de la abuela, surge la luz del día. Llena de gozo, Mónica saluda a su abuela, pero la presencia de su mamita es fugaz. La muchacha mira con impotencia cómo se va difuminando la imagen y grita: "Mamita, no me deje". Andrea se acerca, abraza a su amiga diciéndole que allí no hay nada: "Que lo que usted ve, son disilusiones [sic]".

La doctrina católica considera a la Virgen como la protectora de la humanidad debido a que representa el ideal de la madre que ama a todos sus hijos por igual e intercede por ellos ante Dios. Mónica asocia este ideal de protección con su experiencia personal; por eso, para ella, la Virgen toma el rostro de su mamita a quien recuerda como su única protectora. Hermann Herlinghaus, en Violence without Guilt, cuando analiza los rituales relacionados con la muerte y el exceso de los jóvenes sicarios en las comunas de Medellín, recupera el concepto de lo profano del trabajo del filósofo italiano Giorgio Agamben, quien lo define como "a strategy of returning sacred phenomena and objects that have been kept separate from public domain to general, nonhierarchical use" (125). La vivencia religiosa de Mónica es profana, primero porque hace de lo sagrado algo cotidiano asociándolo con su abuela; segundo, porque la imagen alucinada de la abuela no viene del exterior, más bien nace de lo corporal, de una experiencia que se esfuerza por encontrar refugio para así aliviar su dolor. Herlinghaus, por eso, tiene razón cuando sugiere que la definición de lo profano de Agamben todavía es limitada para entender el mundo de la droga en La vendedora. Allí no únicamente se trata de hacer de lo sagrado algo profano, sino fundamentalmente "to oppose the segregation as hopeless creatures to which these children are exposed with their use of street psychoactives" (200).

En su texto de 1929, "El surrealismo", Benjamin entiende que la iluminación profana no es de carácter mítico, simbólico o teórico, sino de "inspiración materialista, antropológica" (46). Este materialismo antropológico supone que "la acción sea ella misma una imagen" (61) por medio de la cual se quiebra la imaginación conservadora de la burguesía o del racionalismo cientificista: "Tras esta destrucción el ámbito se hace más concreto, se hace ámbito de imágenes: ámbito corporal” (61). Un poco más adelante, escribe: "cuerpo e imagen se interpenetran tan hondamente, que toda tensión revolucionaria se hace excitación corporal colectiva y todas las excitaciones corporales de lo colectivo se hacen descarga revolucionaria” (61-62). ${ }^{8}$

EnSiete ensayos sobre Benjamin, Beatriz Sarlo escribe: "Lailuminación profana capta algo no visto antes: es la potencialidad de conocimiento de lo estético. La condensación formal y semántica de la imagen produce un saber que es social, pero que sólo lo es a

8 Si relacionamos estas ideas con las Tesis, la compleja dinámica entre acción, imagen, cuerpo y lo colectivo sucede en el shock de una constelación -una imagen dialéctica- que une el pasado con el presente. Es decir, cuando la débil fuerza mesiánica que hay en los objetos se transforma en imágenes, a su vez se convierte en iluminaciones profanas que al igual que la pareja revolucionaria formada por Bretón y Nadja, “[h]acen que exploten las poderosas fuerzas de la 'Stimmun’ escondidas en la cosas” (49).

ISSN 0034-9631 (Impreso) 
través de lo artístico” (43-44). Según esta autora, el materialismo de Benjamin se trata de una dialéctica negativa que se aferra a la "nostalgia de la totalidad" y la iluminación profana, por tanto, consiste en la adquisición de una nueva conciencia crítica a través de la experiencia estética. Desde mi lectura, por el contrario, las iluminaciones profanas son una epistemología más ligada a lo corporal y afectivo que a lo racional. Si es que este filósofo deseaba ser el mejor crítico literario de su época, como en efecto se lo manifiesta a su amigo Gershom Scholem, era porque su reflexión quería superar el límite de la razón lógica-especulativa y abrirse a otras formas de conocimiento, entre las que se destaca la experiencia intoxicada. Desde mi punto de vista, el proyecto benjaminiano no coincide con la adquisición de una nueva conciencia crítica y sus iluminaciones profanas, por tanto, son ejemplos de cómo: "[t]hinking is sensualized” (Eiland IX), no sólo en los contenidos, sino también en la forma.

Si regresamos a La vendedora, reconocemos que cuando Mónica imagina a su mamita no lo hace a partir de la racionalización de la precariedad de su vida, sino desde lo más hondo de su vivencia personal. Se trata de una afectividad marginal que descentra el discurso hegemónico de la droga y bajo ningún aspecto consiste en la adquisición de una nueva conciencia desde la cual la muchacha comprende el significado de su vida. ${ }^{9}$ En la medida en que su historia se condensa en la imagen de los "pies descalzos" del personaje de Chinga, quien deambula por las calles y anda a la intemperie, es clara la relación que existe entre cuerpo e imagen en estos delirios. La imagen alucinada es una experiencia concreta que brota de esos "pies descalzos", o sea, de un cuerpo vulnerable. La imagen de su mamita, por tanto, se constituye en una compleja interacción entre desilusiones y esperanzas que deja ver en toda la magnitud el sufrimiento de aquellos niños que no cuentan con la protección de un hogar y cuyo futuro absurdamente se encuentra clausurado.

En este sentido, las iluminaciones profanas de Mónica muestran las contradicciones de una geopolítica que protege unos cuerpos y se desentiende de otros, dejando a estos últimos en una posición de precariedad extrema. ${ }^{10} \mathrm{La}$ experiencia intoxicada en $\mathrm{La}$ vendedora, entonces, interrumpe esta geopolítica en dos momentos. El primero, en tanto la intoxicación le brinda un poco de protección a Mónica, se constituye en un refugio en la imaginación que suspende brevemente la desolación en la que vive; pero esta suspensión no significa una acción revolucionaria en el sentido político-social porque

9 Herlinghaus entiende que existe una guerra de los afectos en la geopolítica contemporánea en donde, por ejemplo, las afectividades marginales del Sur resisten y descentran a los dictados de la cruzada contra la droga diseñada por el Norte. Este autor también opone las categorías benjaminianas de intoxicación e iluminación profana; mi lectura, aunque debe mucho a la noción de afectividades marginales, encuentra complementariedades entre estos dos conceptos de Benjamin.

${ }_{10}$ Judith Butler, en Vida precaria, define la vulnerabilidad a partir de la interdependencia corporal entre el yo y el Otro. También sugiere la existencia de una geopolítica que protege unos cuerpos en desmedro de otros marcando una división arbitraria entre unas "vidas que valen la pena” y otras que "no valen".

$\begin{array}{lllll}\text { ISSN 2154-4794 (Electrónico) } & \text { Revista Iberoamericana, Vol. LXXVII, Núms. 236-237, Julio-Diciembre 2011, 865-883 }\end{array}$ 
la niña continúa viviendo en las calles. El segundo, cuando la película se adentra en los delirios de los niños de la calle, La vendedora en sí misma se constituye en una iluminación profana que no teoriza, sino que se intoxica -actúa-y se deja llevar por las alucinaciones de su protagonista. Al entrar en contacto con los narcóticos, la película deviene en una droga y, por ende, la acción se hace imagen. Pero como bien lo advertía el propio Benjamin, la iluminación profana "no está, desde luego, en los estupefacientes" ("Surrealismo" 46). Si diéramos importancia a la droga por sí misma, estaríamos ante la construcción de un fetiche. La vendedora consiste en un cúmulo de iluminaciones profanas no porque celebre el uso de drogas, sino porque la experiencia intoxicada que allí vemos transmite esa experiencia oprimida que aún no ha sido: la protección de un hogar que no puede materializarse, pero que exige su realización plena.

\section{El DRAMA ANTE LA DESILUSIÓN Y LA ESTÉTICA ALEGÓRICA}

En El origen del drama barroco alemán, Benjamin sostiene que la alegoría barroca es una forma de conocimiento y no una técnica gratuita de producción de imágenes. Este tipo de escritura, señala, considera al mundo como un fragmento amorfo, es decir, como una imagen vacía previamente abandonada por Dios. El barroco, entonces, es una propuesta melancólica que añora recuperar el paraíso y su drama supone el continuo, pero simultáneamente frustrado, intento por restablecer el contacto con lo esencial. Sin embargo, se trata de una melancolía materialista porque aunque, por un lado, el alegorista fija su atención y se resiste a la pérdida de la divinidad, por otro, toda la "sabiduría del melancólico viene del abismo; deriva de la inmersión en la vida de las cosas creadas y nada debe a la voz de la revelación” (144).

En este sentido, Benjamin entiende que la muerte es la clave de la alegoría porque aunque las ruinas del mundo contienen la memoria del paraíso perdido, al mismo tiempo son pruebas irrefutables de su desaparición. El alegorista tiene como principio el desengaño - el luto- mediante el cual transforma al mundo en un tejido de ilusiones o de imágenes despojadas de verdad divina. La alegoría, entonces, por un lado se torna obsoleta instantáneamente y su fugacidad hace que deba reinventarse siempre, enfatizando así en el movimiento. Por otro, sólo se restablece el contacto con lo esencial a través de la historia, pero no en tanto relato cronológico, sino como la puesta en escena de esa profusión de ruinas en que consiste el mundo. Por esta razón, la representación alegórica, en la medida en que tiene plena conciencia de su evanescencia, no concibe el tiempo como una marcha triunfal hacia el progreso, sino por el contrario, como la historia de la decadencia.

"La alegoría del siglo xviI no es convención de la expresión, sino expresión de la convención” (Benjamin, Origen 168), o sea, reconoce la arbitrariedad lingüística por lo que la imagen alegórica no es motivada, sino que se refiere a algo que ya ha abandonado el mundo y, a diferencia del símbolo, carece de la capacidad para reencontrarse plenamente

Revista Iberoamericana, Vol. LXXVII, Núms. 236-237, Julio-Diciembre 2011, 865-883 
con lo esencial. Esto significa que la lógica del ingenio está en la base de la alegoría y gracias a ella se establecen conexiones entre objetos o, con más precisión, imágenes de diversa índole: "Cada persona, cada cosa, cada relación puede significar otra cualquiera" (167). Esta posibilidad infinita de significación implica que el alegorista sea quien impone el significado a las cosas y no al revés. De esta manera, éste se entrega a una incesante producción de alegorías que en lugar de aliviar su drama, por el contrario, lo hunde aún más en el vértigo de la significación infinita y en el abismo de la dispersión.

En el delirio religioso de Mónica, la estatua de la Virgen y la imagen de la abuela forman una alegoría, pero de modo invertido. Lo divino está dado por la remembranza de su mamita, una persona real y corpórea, mientras que lo mundano por el personaje religioso que se representa en la estatua. Aunque la presencia de Dios continúa en el mundo y se materializa en el cuerpo de la mamita, es fragmentaria y está arruinada justamente porque su abuela está muerta. Por esta razón, la historia de la pequeña vendedora antes que un camino de superación personal es uno de decadencia que la conduce a la muerte. El mundo para ella es una catástrofe: vive en las calles, recibe los golpes de los guardias, su novio no la quiere, su familia la rechaza, corre el riesgo de ser violada, la amenazan de muerte, etc. La historia para la pequeña vendedora, entonces, no es una cadena ordenada de eventos, sino una puesta en escena de eventos traumáticos interrumpidos por instantes de felicidad como, por ejemplo, la solidaridad que tiene con sus amigas, aunque no exenta de altibajos y, especialmente, los delirios con su mamita.

Por un lado, Mónica mira a la muerte, pero no para encontrar el sentido del Ser, sino para constatar la precariedad de su existencia. En su vida, cada suceso terrible es seguido por otro que no guarda relación con el anterior, sino únicamente con uno solo: el fallecimiento de su abuela. Asimismo, las imágenes de los delirios también ocurren en escenarios diversos sin que nada conecte una alucinación con otra a excepción de la “imagen divina” alucinada. El mundo para Mónica se parece a la pieza demolida de su ancestro: un conjunto de ruinas, pero todavía con la suficiente fuerza para remitirle a su mamita-Dios. Por ejemplo, el altar en donde la niña delira con el banquete familiar o los zapatos de la abuela esconden una magia que remite al tiempo del paraíso, o sea, cuando Mónica se sentía protegida por un hogar que ya no tiene.

Me gustaría analizar un objeto en especial: la estatua religiosa sobre el puente. Taussig piensa que "es fetichista atribuirle a la imagen, per sé, el papel activo en lo que es una relación recíproca entre el que ve y el que es visto” (Chamanismo 249). La escultura de la Virgen aprobada por el catolicismo, según este autor, es un objeto cuya finalidad es colonizar simbólicamente una geografía apelando para ello a imaginarios muy profundos de la sensibilidad popular. En esta imposición, la imagen religiosa no coincide propiamente con la de la estatua, pero esta última "le garantiza a la imagen una larga vida en su forma material de escultura en la cual persiste con un titilar de esperanza el reflejo de su creación popular” (Chamanismo 217). En el delirio de Mónica, las dos imágenes tienen una importancia asimétrica. Primero, la niña ve la escultura con cierta

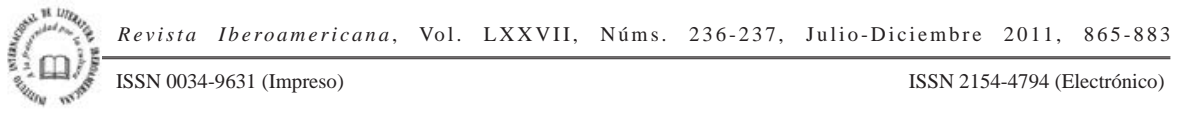


reverencia, pero no le despierta mayor emoción; luego, cuando la imagen de su abuela se toma la estatua, la pequeña vendedora entra en un estado de éxtasis. Esto significa que la estatua sólo adquiere importancia cuando la imagen de la mamita-Dios aparece en ella.

En la escena, la imagen de la abuela se aleja poco a poco de su nieta, al igual que sucede con el Dios de la alegoría. En el momento justo en el que la fusión entre lo sagrado y lo profano alcanza su mayor intensidad, comienza la decadencia de una nueva separación. Mónica sufre una angustia parecida a la de un alegorista barroco y grita: ¡Mamita, mamita!, ¡no me deje!, pero es inútil, lo divino ya ha abandonado el mundo. Los alegoristas del XVII ante la conciencia de su fracaso paradójicamente se entregan con pasión a una profusión de alegorías; la muchacha hace lo mismo, pero su herramienta no es la paleta de un pintor o la pluma de un poeta, sino una botellita de pegamento.

La respuesta que le da Andrea a Mónica es lapidaria aunque llena de afecto: “Eso sólo son disilusiones”. Esta niña, en vez de consolar a su amiga haciéndole entender que está alucinando, da un paso más allá y le informa que sus alucinaciones son el resultado de una desilusión. La historia de la pequeña vendedora en sí misma es una desilusión, un desengaño tremendo, en tanto ella y sus compañeros saben que no tienen futuro. ${ }^{11}$ El mundo en el que les ha tocado vivir es desordenado, un estado de excepción, ${ }^{12}$ en donde la muerte es la costumbre. En la última alucinación, por ejemplo, Mónica muere abandonada, asesinada por uno de los suyos; sin embargo, contradictoriamente se la ve feliz porque se reúne con su abuela; en la alucinación, las dos se abrazan llenas de alegría, mientras en la realidad, la pequeña muere. Es una imagen paradójica porque, a pesar de su insistencia de irse con los muertos, el drama de Mónica significa lo contrario. La pequeña vendedora inhala sacol con desesperación porque gracias a la droga su mamita -su protección- regresa al mundo; es decir, lo que esta niña desea es que la vida sea la norma y no la excepción en su cotidianidad.

Entonces el drama de Mónica a diferencia del barroco no se enfoca en el problema de la soberanía, sino en el de la vida. Ante la inestabilidad del mundo, la niña al contrario que Segismundo, en La vida es sueño de Calderón de la Barca, no aprende a controlar

11 John Beverley, en "Los últimos serán los primeros”, hace una excelente comparación entre la fugacidad de los fuegos pirotécnicos en la película y la fugacidad de la vida de los personajes y actores.

12 Benjamin considera que en el drama barroco (Trauerspiel) prima la idea del mundo como un estado de excepción en donde el orden despareció tras la retirada de la divinidad. El soberano barroco, por eso, está sumido en el drama porque aunque cuenta con el poder absoluto para recomponer el orden perdido, al mismo tiempo vive en la indecisión, pues tiene plena conciencia de la fuerza de sus poderes excepcionales. Benjamin saca su definición del texto de Carl Schmitt, Teología política. Según Agamben, la definición benjaminiana es una crítica a Schmitt porque el soberano no se encuentra fuera del orden, sino al interior del mismo en tanto es una criatura. En este sentido, Benjamin en lugar de encontrar el fundamento de la soberanía en el estado de excepción, se separa de Schmitt en la medida en que el estado de anomia no sirve para imponer un Derecho, sino para interrumpirlo (Agamben, Estado de excepción 106-11).

Revista Iberoamericana, Vol. LXXVII, Núms. 236-237, Julio-Diciembre 2011, 865-883
ISSN 2154-4794 (Electrónico) 
sus emociones ni adquiere la prudencia necesaria para guardar las apariencias. La muchacha tampoco tiene honra que cuidar, por el contrario, ella es un ejemplo de lo que sucede cuando se pierde la honra: “pies descalzos” a merced de cualquier horror. El ingenio que aprende en la calle no le es útil para gobernar a los demás, sino apenas para rebuscarse la vida en un ambiente en el que sabe que sus horas están contadas. Por último, su desengaño no tiene como meta controlar su vanidad. Su desilusión a su pesar es eminentemente vital. La vida para Mónica no es un sueño, sino una pesadilla, pero a diferencia del regenerado Segismundo, ella quiere dejarse seducir por el mundo. Cada uno de sus delirios es una nueva ilusión que intenta re-encantar unas calles, una ciudad, una región, un planeta que ha perdido todo el encanto; pero sus intentos fallan -son una desilusión-, la calle siempre le da un duro golpe y sus anhelos únicamente se hacen realidad a costa de su propia muerte.

Comparemos el drama de Mónica con dos estrofas del poema barroco, "Carta a Lizardo”, del jesuita guayaquileño Juan Bautista Aguirre. La primera estrofa:

¡Ay, Lizardo querido!

si feliz muerte conseguir esperas,

es justo que advertido,

pues naciste una vez, dos veces mueras;

así las plantas, los brutos y las aves lo hacen:

dos veces mueren y una sola nacen.

La última:

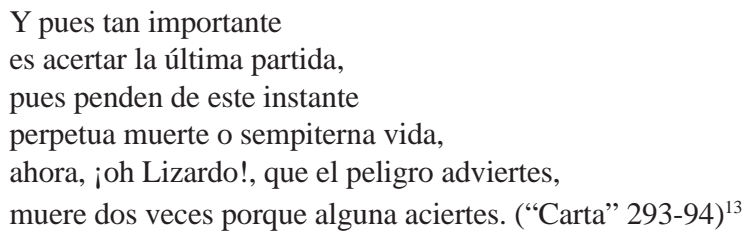

La primera muerte se refiere al nacimiento (la caída), o sea, a la vida terrena. La segunda, en cambio, tiene dos acepciones: primero, las personas mueren dos veces porque nacen y porque mueren; pero en la segunda muerte está en juego la vida eterna o la condenación perpetua. El poema nos advierte que la vida terrenal es pasajera y que la verdadera está en el cielo; por eso, morimos dos veces porque nacer es caer y nuestra

${ }^{13}$ Aunque el poema fue escrito en la segunda mitad del siglo xviII, el barroco fue la cultura hegemónica en América Latina hasta la expulsión de la Compañía de Jesús de las colonias americanas por Carlos III en 1767 con la consiguiente implementación de las llamadas reformas borbónicas.

Revista Iberoamericana, Vol. LXXVII, Núms. 236-237, Julio-Diciembre 2011, 865-883
ISSN 2154-4794 (Electrónico) 
segunda muerte es la que nos abre las puertas del paraíso o las del infierno. En resumen, Aguirre dice que hay que aprender a morir para ganar la gloria celestial.

Teresa de Ávila, en el verso más importante de su famoso poema "Vivo sin vivir en mí”, decía: “Que muero porque no muero” (Collected Works, 375-76), sugiriendo que la muerte terrenal permite el acceso a la vida celestial, la cual es la única verdadera. Mónica, por el contrario, “muere porque no vive y vive porque sí muere”. Su vida no es vida porque, como dicen los místicos barrocos, es una prisión; pero, a diferencia de éstos, se trata sólo de una agonía porque ni siquiera alcanzará la adolescencia y todo habrá acabado después de su deceso; es decir, su muerte no conduce a la salvación, sino que es el triunfo de la violencia absurda que trae consigo el no futuro. Esta niña "muere porque no vive y vive porque muere”, es decir, su vida no es vida porque, como dicen los barrocos, es un infierno; pero, a diferencia de éstos, vive sólo una agonía porque ni siquiera podrá llegar a la adolescencia y todo habrá acabado después de morir. En otras palabras, su deceso no significa la puerta a la otra vida, sino el triunfo de una violencia absurda que continúa expandiendo el reino de la muerte.

La pequeña vendedora, por eso, no sucumbe ante el estoicismo que espera con tranquilidad la muerte ni se apasiona con el nihilismo destructor. Su vida es un canto a la supervivencia porque, a pesar de que sabe que no tiene futuro, lucha por salir de la evanescencia aferrándose a unas imágenes también fugaces. En otras palabras, sus ilusiones (iluminaciones profanas) exigen que la experiencia frustrada, lo que aún no ha sido, la vida, tome cuerpo en el presente redimiendo lo que ha sido-su gran desilusión-. “El paraíso es sueño”, ese es el desengaño de Mónica porque no le basta el consuelo de una vida después de la muerte para acabar con la agonía del no futuro. Su drama consiste en aferrarse una y otra vez a la ilusión de su mamita, aunque la imagen de su abuela paradójicamente es tan sólo fruto de una gran desilusión, como lo dice Andrea.

En Alegorías de la derrota, Idelber Avelar relaciona el concepto benjaminiano de la alegoría con las ideas freudianas de duelo y melancolía. En primer lugar, indica que la alegoría "florece en un mundo abandonado por los dioses, mundo que, sin embargo, conserva la memoria de ese abandono y no se ha rendido todavía al olvido" (18). En segundo lugar, el duelo supera la pérdida gracias a que "la separación entre el yo y el objeto perdido aún puede llevarse a cabo, mientras que en la melancolía la identificación con el objeto perdido llega a un extremo en el cual el mismo yo es envuelto y convertido en parte de la pérdida” (19). De este modo, Avelar acepta la derrota como la “determinación irreductible de la escritura” (29) en una época en donde el heroísmo y el optimismo han dejado de ser una opción deseable. ${ }^{14}$ El trabajo del duelo, de este modo, se constituye en un imperativo y "presupone sobretodo la capacidad de contar

${ }^{14}$ Avelar estudia la literatura de la posdictaduras en el Cono Sur y, por eso, según é, la posdictadura contemporánea es una forma de decadencia en donde la hegemonía del Estado ha sido reemplazada por la del Mercado a través de dictaduras furiosas.

Revista Iberoamericana, Vol. LXXVII, Núms. 236-237, Julio-Diciembre 2011, 865-883 ISSN 0034-9631 (Impreso) 
una historia sobre el pasado” (34). Las imágenes alegóricas, en cambio, consisten en la presencia fantasmal de la pérdida, es decir, lo reprimido que se resiste a desaparecer. Las alegorías de la derrota, entonces, narran sus historias a partir de lo intempestivo, es decir, desde “aquello que piensa el fundamento de su presente, desgarrándose de él para vislumbrar lo que ese presente tuvo que ocultar para constituirse en cuanto tal-lo que, en otras palabras, a ese presente le falta” (35).

En The Letter of Violence, Avelar plantea un proyecto terapéutico que asume la violencia como un elemento constitutivo del sujeto moderno y del propio lenguaje. Por un lado, se cuida de confundir el duelo tanto con el regreso a un orden anterior que erróneamente se supone como no violento como con la manía de la etapa triunfante del duelo que recentra al sujeto y cae en la violencia del heroísmo o el optimismo. Por otro, identifica un conflicto al interior del lenguaje porque el acto de dar un nombre general (sustantivo común) al dolor implica quitarle la singularidad de su experiencia (nombre propio). Sin embargo, piensa que si se quiere transmitir esa experiencia, es necesario establecer un lenguaje general que permita hablar de ella; es decir, plantea la posibilidad de un lugar virtual -un tercer espacio- desde donde podamos ser testigos del dolor para desde allí hablar de él y construir una subjetividad postraumática colectiva.

The Letter of Violence también relaciona dos textos de Benjamin: Para una crítica de la violencia (1921) y Tesis de la filosofía de la historia (1940). El puente lo tiende a partir de Los espectros de Marx, de Jacques Derrida, gracias al cual vincula la categoría de los espectros con la propuesta utópica benjaminiana. Los espectros, a diferencia de los espíritus, se constituyen en una memoria viva -lo que aún no ha sido- que ronda por el presente y que está cargada de una fuerza perturbadora. Asimismo, los espectros se relacionan con la categoría freudiana de lo reprimido, cuyo retorno a la conciencia implica el regreso de ese algo que incomoda, pero que paradójicamente nunca ha dejado de estar presente. José M. Cuesta, en Los juegos del duelo, desde una lectura similar, considera que la remembranza -la memoria viva- saca a la luz lo oprimido, es decir, lo suprimido y reprimido, con el propósito de que lo aún no sido -la felicidad-reemplace a lo sido y que el dolor -lo sido- sea algo no consumado. El duelo, entonces, significa el retorno de lo reprimido, quien siempre vuelve con “diferente ropaje” (iterabilidad), para interrumpir cuando no superar la experiencia oprimida que viene desde el pasado y sigue viva en el presente.

Si consideramos la historia de Mónica como una experiencia oprimida, es claro que su imagen es un espectro que molesta a la sociedad contemporánea. Las imágenes de los niños de la calle de Medellín remiten a lo intempestivo despertando memorias desconocidas en los espectadores al ponernos frente a lo reprimido y suprimido: lo suprimido porque vemos personas a las que generalmente les está negado el mundo de la representación y lo reprimido porque se ve aquello que violentamente se intenta eliminar. Asimismo, si consideramos que la muerte de la abuela sumergió a Mónica en

\footnotetext{
Revista Iberoamericana, Vol. LXXVII, Núms. 236-237, Julio-Diciembre 2011, 865-883
ISSN 2154-4794 (Electrónico)
} 
la melancolía, es claro que la pequeña no se aferra propiamente a la imagen de su abuela, sino que esta imagen es esa memoria viva -la falta de un hogar-que demanda realizarse.

Sin embargo, el drama de Mónica no coincide con una actitud de duelo en el sentido en que lo propone Avelar, sino que se trata de una melancolía materialista. Esta niña vive en el desengaño y la búsqueda de su mamita es un esfuerzo constante y desesperado para no perder la ilusión: una actitud optimista que reencanta el mundo a pesar de la precariedad en la que vive. La pequeña vendedora no puede darse el lujo de admitir la derrota, su profunda melancolía, aunque se manifiesta en la imagen alegórica de un cadáver, es ante todo por la vida, o sea, su pérdida es la vida misma y, de este modo, aceptar la pérdida para ella significa aceptar la muerte. Asimismo, en tanto Mónica tiene plena conciencia de que puede morir en cualquier instante, su trauma no sólo está en el pasado -el hogar que perdió-, sino fundamentalmente en el futuro: la fugacidad de su vida. La pregunta, entonces, sería ¿cómo puede aceptar la derrota si su pérdida está en el no futuro?

Avelar podría responder que la imagen de la abuela se constituye en un lugar virtual desde el cual la muchacha podría ser testigo de su experiencia dolorosa para poder hablar de ella y desde allí construir una subjetividad postraumática colectiva. Si pensamos en la audiencia, esta idea funciona porque los espectadores generamos ese lugar virtual por medio de la película y así observamos ese presente desgarrado. Sin embargo, para los actores y los personajes de la película no funciona porque ellos están abocados a otra urgencia: no tienen futuro. El personaje de Mónica no puede pensar la imagen de su mamita como un tercer espacio porque ella está completamente identificada con esta imagen. Si la niña adquiriere una conciencia distanciada, se dejaría absorber por el desengaño, su drama acabaría y se entregaría a la muerte. Pensemos asimismo en los actores o en Mónica Rodríguez, las imágenes de sus intoxicaciones son "las únicas personas" con quienes podían conversar, "sus mejores amigos”. En este sentido, estos niños no ven sus traumas en las imágenes ni construyen una subjetividad postraumática a través de ellas. Ellos sólo pueden contar sus penas a quienes asoman en sus alucinaciones y, por tanto, entran en las imágenes de sus delirios sin poder tomar distancia con las personas que allí aparecen. ${ }^{15}$

Aunque los espectadores sí podemos generar un tercer espacio, creo que el logro más significativo de La vendedora está en que el filme evita un distanciamiento entre la audiencia y los personajes. Su objetivo es conseguir una identificación profunda entre ambos porque lo que está en juego aquí no es el trauma de los espectadores ni la aceptación de la derrota, sino la urgencia de unas vidas que van a perderse muy pronto. Por eso, me parece que más que en un espacio virtual -que indudablemente lo es- la

${ }^{14}$ En "Las ciudades del yagé”, Michael Taussig analiza la relación entre las imágenes dialécticas y la intoxicación. Utilizo la idea de "entrar en las imágenes” tal como este autor lo propone en este texto.

Revista Iberoamericana, Vol. LXXVII, Núms. 236-237, Julio-Diciembre 2011, 865-883 ISSN 0034-9631 (Impreso) 
riqueza de la película está en la intoxicación y la construcción de experiencia colectiva en donde la audiencia no es la que tiene la última palabra porque la experiencia más dolorosa la sufren los actores. La vendedora supera el no futuro gracias a las historias de vida que allí aparecen además de que muchos de los actores sobreviven únicamente en sus imágenes. Estas imágenes se mimetizan con las alucinaciones de los niños de la calle y, en este sentido, la película nos propone entrar en las imágenes con el propósito de que renarremos nuestra experiencia involucrándonos de lleno con la de aquéllos que están abocados a la evanescencia y a la irrelevancia en el mundo contemporáneo.

\section{LA REDENCIÓN MESIÁNICA Y LA PROFUSIÓN: UN RESCATE DEL VALOR DE LA VIDA}

Herlinghaus señala que la experiencia alucinada de Mónica funciona como "a negation of the aberrant effects that drugs and glue sniffing cause on teenaged boys" (199); es decir, es una afectividad marginal que cuestiona el supuesto "that relates adolescent deviance among the poor essentially to drug trafficking and abuse” (199). Por esta razón, considera necesario no reducir la imagen alucinada de la abuela a un tropo nostálgico y, en cambio, propone analizar el sentido que tienen los objetos en $L a$ vendedora. En la película, señala, existe una "reimagination of consumption" (199) mediante la cual el valor de cambio cede su preeminencia a una "ethics of the gift" (202). Mónica no piensa en el valor comercial de los objetos; tampoco les impone una función utilitaria. Ella entrega sus cosas sin esperar nada a cambio. Así, según este crítico, cumple con el ideal franciscano: simples usus facti. Este autor concluye que tanto la ética del regalo como los delirios de la muchacha son una reafirmación "of the use value of life itself" (202).

Mi interpretación, aunque se vale de los argumentos de Herlinghaus, también los traiciona, porque, desde mi lectura, la ética del regalo coincide con la redención materialista de Benjamin. Al igual que los alegoristas del xviI, en su amor por alcanzar lo divino, Mónica traiciona el ideal trascendental, entregándose al mundo porque cada objeto por más pequeño que sea le sirve para recuperar su comunicación con su mamita-Dios. Su amor por lo terreno hace que ella se resista al no futuro y, por eso, da un valor especial a cada cosita que encuentra. La ética del regalo de Mónica, de este modo, guarda estrecha relación con una profusión alegórica de objetos, la cual coincide con lo que comúnmente se denomina estética kitsch.

El reloj que Mónica piensa regalar a su novio tiene dibujitos y colores que fascinan al Zarco, fascinación que desembocará en la muerte de la pequeña. A Judy, a Claudia y a Marcela les encanta una tarjetita con el siguiente mensaje: "Mi amor por ti sube hasta las estrellas". La misma Judy tiene un cuaderno en el que pega todo tipo de recortes y transcribe las frases de amor que saca de las canciones populares. La pieza de las muchachas está saturada con recortes de revistas y dibujos como, por ejemplo, un jardín de rosas rojas, estrellas diversas, un ángel, un leopardo y un osito, todos pintados

\footnotetext{
Revista Iberoamericana, Vol. LXXVII, Núms. 236-237, Julio-Diciembre 2011, 865-883
ISSN 2154-4794 (Electrónico)
} 
con colores muy vivos. En otro momento, la pequeña vendedora robó una estrellita de Navidad de una discoteca que luego servirá para adornar el nacimiento de Viviana. Este nacimiento es aún más interesante. Allí se encuentran mezclados objetos de diferente procedencia sin un orden específico; o sea, se condensa una imaginación popular en la cual todas las cositas son una chimba -chéveres-y adquieren una importancia inusual. Los nacimientos y las festividades navideñas de los pobres en Medellín proliferan los objetos, la mayoría de ellos baratijas sin ninguna relación con lo religioso. En este sentido, su religiosidad, más que por un mensaje teológico, está dada por la cotidianidad. Los objetos del nacimiento están allí no porque se refieran a lo celestial, sino por un apego a lo concreto en donde ellos por sí mismos son hermosos sin importar su procedencia.

Hannah Arendt, en Tiempos de oscuridad, analiza la pasión de Benjamin por el coleccionismo. Nos cuenta que este autor "busca cosas extrañas que son consideradas sin valor” (205) y esta actitud, según ella, coincide también con esa otra pasión por mirar las ruinas del pasado. Para Benjamin, señala Arendt, “[c]oleccionar es la redención de las cosas, que es complementar la redención del hombre” (204). El coleccionismo benjaminiano, en este sentido, busca un valor alternativo en los objetos que los libere de la dictadura del valor de cambio. Este tipo de coleccionismo, me parece, coincide con lo que identifico con la estética redentora de la profusión. La redención profana en La vendedora, entonces, no está en los templos o lugares santos, sino que coincide con el trabajo de Galileo y su compañero, quienes asoman fugazmente en la película. Ellos jalan una carreta en donde ponen "profusamente" la basura que recogen de las calles. El esfuerzo de estos chicos, por tanto, devuelve el valor a aquellos desechos que "no valían la pena”.

Cuando Mónica usa los zapatos de su mamita-Dios, estos zapatos divinos protegen sus "pies descalzos" dándole una sensación de seguridad y felicidad que nos transmite a través de su sonrisa plena; mientras los usa, el mundo se reencanta y todo es hermoso. Me gustaría proponer además otra lectura. La felicidad de la pequeña vendedora cuando regresa al centro de Medellín también se da justo después de su encuentro con Galileo y su amigo. El saludo cariñoso que tiene con estos personajes parece un detalle sin importancia, pero me parece que allí ocurre una redención mesiánica que llena de alegría a Mónica en tanto ha ocurrido un encuentro con quienes valoran los desechos.

Si pensamos que en Colombia se considera a las personas que viven en la calle como desechables, la acción de Galileo y su amigo básicamente devuelve el valor a las vidas de los niños sin hogar, quienes arbitrariamente "han dejado de valer la pena". Asimismo, si cada segundo es una puerta por donde puede ingresar el Mesías, en $L a$ vendedora, una de esas puertas es la toma en la que asoman Galileo y su compañero. Primero, su duración es tan sólo de un segundo, un relámpago que ni bien lo vemos desaparece. Apenas Mónica los saluda, ellos siguen su camino y no se los ve más. Segundo, Galileo no viene del exterior, pertenece al universo de la marginalidad; o sea, su vida al igual que la de Mónica tampoco "vale la pena”.

Revista Iberoamericana, Vol. LXXVII, Núms. 236-237, Julio-Diciembre 2011, 865-883 ISSN 0034-9631 (Impreso) 
Podríamos pensar que la presencia de Galileo es completamente contingente porque si se lo elimina, la historia no se vería afectada. Sin embargo, en la medida en que este joven es uno de aquellos “desechables” de Medellín, entonces él no es una mera decoración, sino una persona que pertenece al mundo marginal con el que trabaja la película. Si mi lectura es correcta, en mi exposición he condensado a dos muchachos en la imagen de uno solo. Así borro la presencia de uno de ellos porque Galileo tiene un nombre y el otro no. El primero es lo nombrado, mientras que el segundo carece de nombre. En este sentido, la redención propiamente no vendría de Galileo, sino de su compañero para quien también la basura tiene una importancia capital en su sobrevivencia. Pero si profundizamos un poco más, el adolescente sin nombre no es un Redentor, sino que su acción es la redentora -con minúsculas. Una acción cotidiana que no tiene un sujeto, no importa si se llama Galileo, el Zarco, Mónica o de otra manera. La acción mesiánica, entonces, está en el drama de todos aquellos niños a quienes no vemos ni escuchamos y que además ignoramos por completo. Todos estos muchachos se esfuerzan por dar un valor a algo que sin motivo lo ha perdido. Ellos, como Mónica, se aferran a la vida en un mundo que macabramente los conduce a la muerte. La muerte se ha apoderado de su mundo no como una posibilidad que ocurrirá en el futuro, sino como un presente monstruoso que los aniquila y les priva del futuro.

Si La vendedora logra que la audiencia dé valor a la vida de sus actores se habrá producido una redención mesiánica. No obstante, esta redención puede o no suceder. Muchos espectadores desconocen que existe este tipo de filmes, otros los pasan por alto y hay quienes los desprecian; pero si unos se identifican con el drama de Mónica, la película habrá “valido la pena”. La vendedora, entonces, en sí misma contiene una débil fuerza mesiánica que, cuando logra unir la historia de vida de sus actores con la experiencia de los espectadores por medio de los personajes, hace estallar los dictados de la geopolítica global y devuelve el valor a la vida de quienes injustamente han sido transformados en desechables.

\section{BiBLIOGRAFÍA}

Agamben, Giorgio. Estado de excepción. Homo sacer II, I. Buenos Aires: Adriana Hidalgo, 2004.

Aguirre, Juan Bautista. “Carta a Lizardo, persuadiéndole que todo lo nacido muere dos veces para acertar a morir una”. Letras de la audiencia de Quito período jesuítico. Hernán Rodríguez Castelo, sel., pról. y cron. Caracas: Biblioteca Ayacucho, 1984. Arendt, Hannah. Hombres en tiempos de oscuridad. Barcelona: Gedisa, 2001.

Avelar, Idelber. Alegorías de la derrota: la ficción postdictatorial y el trabajo del duelo. Santiago de Chile: Cuarto Propio, 2000.

The Letter of Violence: Essays on Narrative, Ethics, and Politics. New York: Palgrave Macmillan, 2004.

\footnotetext{
Revista Iberoamericana, Vol. LXXVII, Núms. 236-237, Julio-Diciembre 2011, 865-883
ISSN 0034-9631 (Impreso)
} 
Benjamin, Walter. Haschisch. Madrid: Taurus, 1974.

"El narrador". Para una Crítica de la violencia y otros ensayos, Iluminaciones

IV. Madrid: Taurus, 1998.

El origen del drama barroco alemán. Madrid: Taurus, 1991.

"Para una Crítica de la violencia”. Para una Crítica de la violencia yotros ensayos,

Iluminaciones IV. Madrid: Taurus, 1998.

"Sobre el lenguaje en general y el lenguaje de los seres humanos". Para una

Crítica de la violencia y otros ensayos, Iluminaciones IV. Madrid: Taurus, 1998.

“El Surrealismo”. Imaginación y sociedad, Iluminaciones I. Madrid: Taurus, 1991.

Tesis sobre la historia y otros fragmentos. Bolívar Echeverría, trad. México:

Contrahistorias, 2005.

Beverley, John. "Los últimos serán los primeros": Notas sobre el cine de Gaviria”. Imagen y subalternidad, el cine de Víctor Gaviria. Luis Duno-Gottberg, coord. Caracas: Cinemateca Nacional de Venezuela, 2003.

Buck-Morss, Susan. The Dialectics of Seeing, Walter Benjamin and the Arcades Project. Cambridge, MA: MIT, 1991.

Butler, Judith. Vida precaria. El poder del dueloy la violencia. Barcelona: Paidós, 2006.

Calderón de la Barca, Pedro. La vida es sueño. Barcelona: Plaza \& Janes, 1999.

Cuesta Abad, José M. Juegos del duelo. La historia según Walter Benjamin. Madrid: Abada, 2004.

Echeverría, Bolívar. “El ángel de la historia y el materialismo histórico”. La mirada del ángel, sobre el concepto de la historia en Walter Benjamin. México: Era, 2005.

"Introducción, Benjamin, la condición judía y la política”. La mirada del ángel, sobre el concepto de la historia en Walter Benjamin. México: Era, 2005.

Valor de uso y utopía. México, D.F.: Siglo XXI Editores, 1998.

Eiland, Howard. Introduction. Walter Benjamin, On Hashish. Cambridge: Belknap Press of Harvard UP, 2006.

Forster, Ricardo. Walter Benjamin y el problema del mal. Buenos Aires: Altamira, 2003.

Goggel, Erwin, Santiago Navarro y Víctor Gaviria, dirs. Cómo poner a actuar pájaros. Colombia, 1999.

Herlinghaus, Hermann. Violence Without Guilt: Ethical Narratives from the Global South. New York: Palgrave Macmillan, 2008.

Herrera, Lizardo M. Ética, utopia e intoxicación en Rodrigo D. no futuro y La vendedora de rosas. Tesis doctoral. Pittsburgh: University of Pittsburgh, 2009.

Sarlo, Beatriz. Siete ensayos sobre Walter Benjamin. Buenos Aires: Fondo de Cultura Económica, 2006.

Taussig, Michael. Chamanismo, colonialismo y el hombre salvaje, un estudio sobre el terror y la curación. Bogotá: Norma, 2002.

"Las ciudades del yagé”. Primera Revista Latinoamericana de Libros. (sept-nov 2007). <http://www.midoeditores.com>. 1 dic. 2010.

Revista Iberoamericana, Vol, LXXVII, Núms, 236-237, Julio-Diciembre 2011, 865-883 
Teresa de Ávila, Santa. The Collected Works of St. teresa of Avila. Volume Three. Washington: Institute of Carmelite Studies, 1985

La vendedora de Rosas. Víctor Gaviria. Dir. Nirvana Films, S.A., 1998.

Revista Iberoamericana, Vol. LXXVII, Núms. 236-237, Julio-Diciembre 2011, 865-883
ISSN 2154-4794 (Electrónico) 
